\title{
Land Suitability Analysis for Orange \& Pineapple: A Multi Criteria Decision Making Approach Using Geo Spatial Technology
}

\author{
Pratibha T. Das, S. Sudhakar \\ North Eastern Space Applications Centre, Department of Space, Government of India, Umiam, India \\ Email: thakuriapratibha@rediffmail.com
}

Received December 17, 2013; revised January 17, 2014; accepted January 25, 2014

Copyright (C 2014 Pratibha T. Das, S. Sudhakar. This is an open access article distributed under the Creative Commons Attribution License, which permits unrestricted use, distribution, and reproduction in any medium, provided the original work is properly cited. In accordance of the Creative Commons Attribution License all Copyrights (C) 2014 are reserved for SCIRP and the owner of the intellectual property Pratibha T. Das, S. Sudhakar. All Copyright (C) 2014 are guarded by law and by SCIRP as a guardian.

\begin{abstract}
Land evaluation procedure given by FAO for soil site suitability for various land utilization types for rainfed agriculture has been used to assess the land suitability for khasi mandarin orange and pineapple in East Khasi Hills District of Meghalaya. The database on soil and land use/land cover was generated from IRS-P6 remote sensing satellite data, soil survey and laboratory analysis of soil samples to perform an integrated analysis in the Geographic Information System environment. Different soil chemical parameters and physical parameters were considered to evaluate soil site suitability for orange \& pineapple. Different thematic layers were derived from soil map by using ArcGIS software. Subsequently all of them were overlaid and integrated in GIS environment and suitability criteria was applied to the resulted composite map and generated land suitability map for orange and pineapple. The result indicated that the soil sites of the study area are highly to marginally suitable for mandarin orange whereas it is marginally suitable for pineapple. The study reveals that highly suitable areas for orange are found in the Cherapunjee and Mawsynram area that covers $34.5 \mathrm{Sq} . \mathrm{Km}$ areas. Moderately suitable (37\% of TGA) and marginally suitable (24\% of TGA) areas are found only because of slope constraint $(8 \%-30 \%$ slope). The hills with deep gorges and ravines on the southern portion of the district is found not suitable for orange plantation because of steep slopes $(>30 \%)$ and stoniness. Land suitability analysis for pineapple showed that $81 \%$ area of total geographical area of the district is marginally suitable and $19 \%$ area is not suitable to support the crop. The district is marginally suitable because of topography (slope and erosion), soil fertility (base saturation and CEC) and climate.
\end{abstract}

\section{KEYWORDS}

Khasi Mandarin Orange; Pineapple; Site Suitability Analysis; Soil; Slope; Remote Sensing; GIS

\section{Introduction}

Land users and planners need basic soil information, problems and potential and suitability of soils for various crops for sustained agricultural production. The information on the spatial distribution and suitability of various types of soils to various types of crops is crucial for planners and agricultural scientists to initiate and encourage farmers to practice cropping systems based on soil potential to various crop categories. Again optimizing crop production can be achieved through sustainable agriculture or farming. The concept of sustainable agri- culture or farming involves producing quality products in an environmentally benign, socially acceptable and economically efficient way [1] ensuring optimum utilization of the available natural resource for efficient agricultural production. In order to comply with these principles of sustainable agriculture, one has to grow the crops where they suit best and for which first and the foremost requirement is to carry out land suitability analysis [2]. Land suitability is a function of crop requirements and land characteristics [3]. Matching the land characteristics with the crop requirements gives the suitability. So, sui- 
tability is a measure of how well the qualities of a land unit match the requirements of a particular form of land use [4]. Land suitability analysis has to be carried out in such a way that local needs and conditions are reflected well in the final decisions [5]. For land suitability analysis, soil information in the form of map and report is a vital component. The utility of soil-land resource information for proper agricultural land use was proposed by Dumanski et al. (1987) [6]. The land evaluation system of FAO (1983) was based on land qualities as related to individual crops that was used to develop the crop requirements based on experiences in tropical areas [7]. This land evaluation system for land use was earlier adopted to derive land suitability map in western parts of Maharashtra [8] and in Nera watershed of Himachal Pradesh [9]. Spatial distribution of cotton crop in relation to soil characteristics was studied by Ramarao (2001) [10] using RS \& GIS techniques for Guntur district of Andhra Pradesh, India. A study was conducted to inventories the soils of Patloinala micro watershed, West Bengal on cadastral level using remote sensing data. Based on the soil resource data coupled with land capability and soil site suitability for crops, a land use plan has been suggested using GIS to achieve maximum return in terms of agricultural production [11]. These show that RS \& GIS can be used very effectively for land suitability analysis.

Pineapple is the second most important fruit crop of the North Eastern Region of India both in terms of area under plantation and production. Its area of cultivation is estimated to be about 20,126 hectares with an annual production of 167,518 tons in NER. Manipur stands first in production while Meghalaya has the largest area under pineapple cultivation and is second in production [12]. Citrus is an important group of fruits of NER and it comes third in terms of area and production. Among the different states of this region, Meghalaya is the leading state in both area and production followed by Manipur, Assam, Tripura, Mizoram, Nagaland and Arunachal Pradesh [13].

In Meghalaya Pineapple, Citrus fruits mostly Khasi mandarin orange, Banana, Arecanut and Papaya are the major fruit crops grown in the side slopes of hill either as pure crops or mixed with other plantations. Arecanut plantation covers the highest area followed by pineapple, citrus, banana and papaya. The production is highest in case of pineapple followed by orange, banana, papaya and arecanut [14]. Khasi Mandarin orange is the most important fruit of East Khasi Hills district of Meghalaya both in terms of area and production. The second most important fruit is pineapple in terms of area (Figure 1). Therefore both this crop is selected for land suitability analysis so that farmers can utilize their soils for area expansion in East Khasi Hills district based on its potentialities and problems.

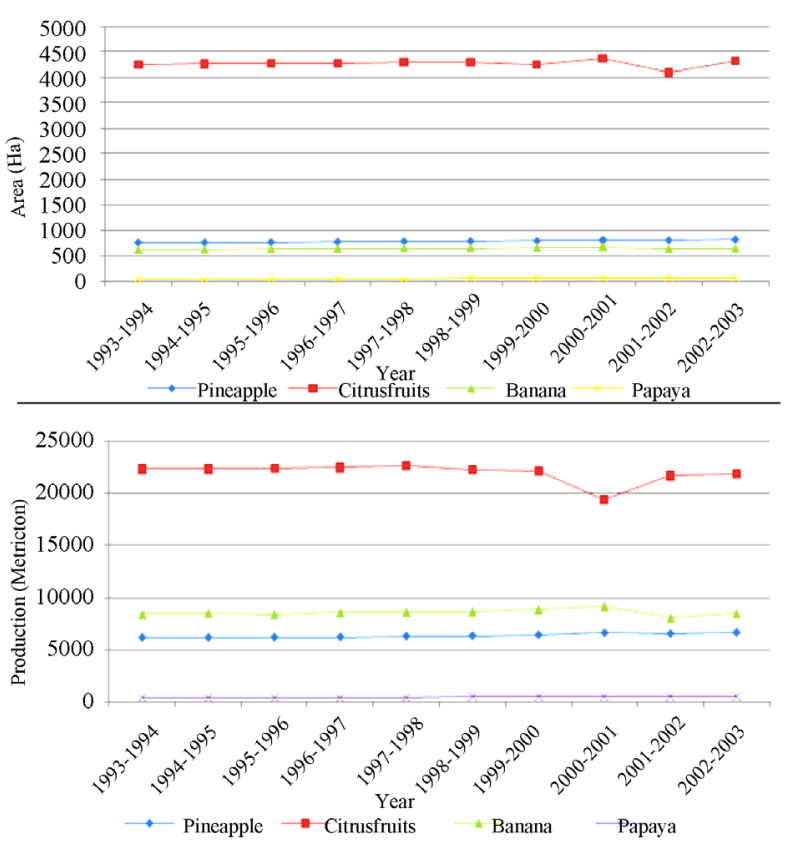

Figure 1. Changes in area and production over years in East Khasi Hills district (Source: Directorate of Economics and Statistics, Govt. of Meghalaya).

\section{Materials and Methods}

\subsection{Study Area}

East Khasi Hills is one of the 7 districts of the state of Meghalaya. The district occupies an area of 2748 Sq.Km with population of 660,923 . It lies between $25^{\circ} 07^{\prime} 13^{\prime \prime}$ to $25^{\circ} 41^{\prime} 16^{\prime \prime} \mathrm{N}$ latitute and $91^{\circ} 21^{\prime} 24^{\prime \prime}$ to $92^{\circ} 09^{\prime} 27^{\prime \prime} \mathrm{E}$ longitude. The district is bounded by Ri-Bhoi district on the north, Karbi Anglong district on the north east, Jaintia Hills district on the east, Bangladesh on the south and West Khasi Hills district on the west (Figure 2). The district is mostly hilly with deep gorges and ravines on the southern portion. The most important physiographic features of the district is the Shillong Plateau interspersed with river valley, then fall sharply in the southern portion forming deep gorges and ravine in Mawsynram and Shella-Bholaganj bordering Bangladesh. The climate of the district ranges from temperate in the plateau region to the warmer tropical and sub-tropical pockets on the Northern and Southern regions. The whole of the district is influenced by the south-west monsoon which begins generally from May and continues till September. The weather is humid for the whole year except for the relatively dry spell usually between December and March.

\subsection{Soill Map}

Digital data of IRS-P6 (Resourcesat-1) LISS III sensor of October, 2005 (Spatial resolution of $23.5 \mathrm{~m}$ ) was used to prepare physiography, land use land cover and parent 


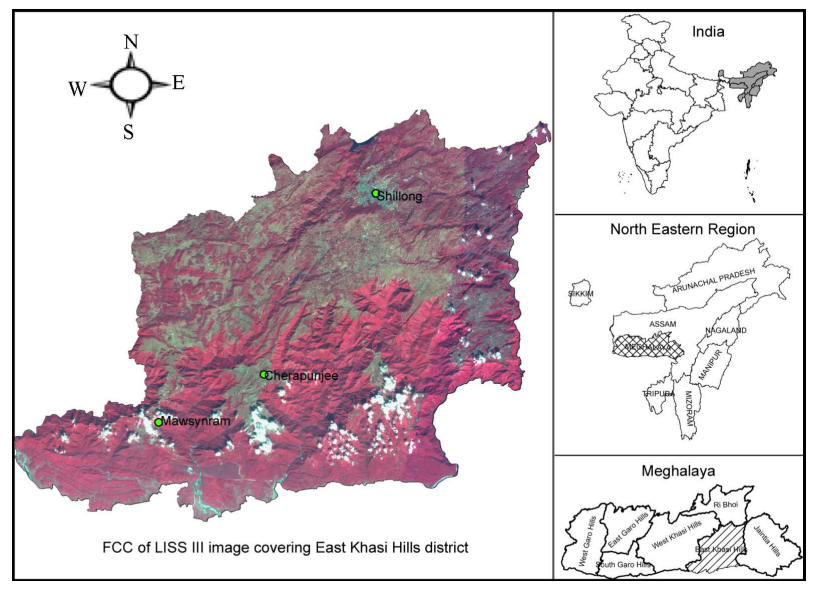

Figure 2. Location of the study area.

material type map from which soil map was derived by incorporating morphological characteristics and laboratory analysis data of soil profile. The methodology followed for extraction of information from satellite data is essentially of standard visual interpretation based on tone, texture, shape and size [15]. The slope map was derived from DEM generated from topomaps $(1: 50 \mathrm{~K})$. Soil profiles were studied based on variations in physiographic unit, parent material type, land use land cover and slope map. Each map represents the factors which influence soil formation. All theses maps were transferred to GIS environment and overlaid and used as base map for field survey and soil sample collection. Based on variations of these factors, 35 sites have been selected for detailed morphological study of the soils. Soil profiles were exposed and studied the morphological characteristics of each soil profile in detail and recorded in a standard format following the soil survey manual [16] and FAO (1977) [17] guidelines for soil profile descriptions. Soil site information was also recorded. Horizon wise soils were collected analyzed for physical and chemical properties to incorporate the results with field observations and the soils were classified taxonomically following Keys to soil Taxonomy. The soil boundary was delineated based on the boundary inferred by combination of different layers representing soil forming factors that were used in the base map. The polygons representing similar physiographic unit, parent material, slope and vegetation cover was put under same soil type which is confirmed by image characteristics and field survey. Different kind of soil can be expected if there is any change of these factors [18]. The soil map was used for land evaluation. ArcGIS software has been used for visual interpretation of images, attribute database generation and its linking to soil polygons.

\subsection{Slope Map}

The diagnostic factor of topography (t) is a combination of landform and slope gradient. The landform and slope has predominant effect on the retentively of water during the growing period. Information on landform in terms of per cent slope is derived from DEM (Digital Elevation Model) generated using topographic map $(1: 50,000)$. The slope map is reclassified based on crop requirements and a map is generated showing the limitations of slope to the crop.

\subsection{Land Evaluation}

The land evaluation was done as per FAO (1983) [19] guidelines. This approach is based on the matching of qualities of different land units in a specific area, with the requirements of actual or potential land use. In order to develop a set of themes for evaluation and ultimately to produce a suitability map for orange and pineapple, the crop requirement in terms of land qualities was used as given by Sys et al. (1993). Each characteristic is considered as a thematic layer in the GIS. Nine attributes namely; soil depth, drainage, flooding, texture, gravel/ stoniness, $\mathrm{pH}$, organic matter, CEC and base saturation were added to the polygon attribute table. The attribute values were then compared to the crop requirements and assigned values of degree of limitation ranging from 0 (suggesting no limitation) to 4 (suggesting very severe limitation) and soil limitation map is generated. Each of land qualities with associated attribute data is overlaid in a GIS environment and generated ten thematic layers. The diagnostic factors of each thematic layer were assigned values of degree of limitation ranging from 0 (suggesting no limitation) to 4 (suggesting very severe limitation) for mandarin orange and pineapple using the individual crop requirements. These ten layers are then spatially overlaid to produce a resultant polygon layer. Each polygon of the resultant polygon layer has $10 \mathrm{val}-$ ues of degree of limitation depicting limitation for each thematic layer input. Based on number and the intensity of limitations suitability classes were determined and entered as attribute of polygons of the resultant composite layer which yields a suitability map (Figure 3).

\subsection{Accuracy Assessment}

The accuracy of maps prepared under this study was assessed by quality check team of North Eastern Space Applications Centre by verifying field photos, morphological \& chemical properties of soil against the ground control pints collected with GPS.

\section{Results and Discussion}

\subsection{Soils}

The study reveals that soils of the district vary from Ultisols (50\%), Alfisols (31\%) and Inceptisols (19\%) with 
udic moisture regimes and thermic temperature regimes (Figure 4). Soils are moderately deep to very deep, well drained to excessively drained, acidic in reaction which ranges from moderately acidic to slightly acidic ( $\mathrm{pH} 5.12$ - 5.96). About $46 \%$ area of the district is moderately acidic and rest belongs to slightly acidic. Soil texture varies from clay to sandy clay loam. Majority of the soils covering about $85 \%$ of the total geographical area is loamy (Clay loam and sandy loam) and about 4\% and 5\% are clayey and sandy clay respectively. The organic matter content of soil is high which ranges from $1.32 \%$ to $4.23 \%$. More than $40 \%$ area of the district has got $2.04 \%$ - $2.78 \%$ organic carbon. Only $2.74 \%$ area of total geo-

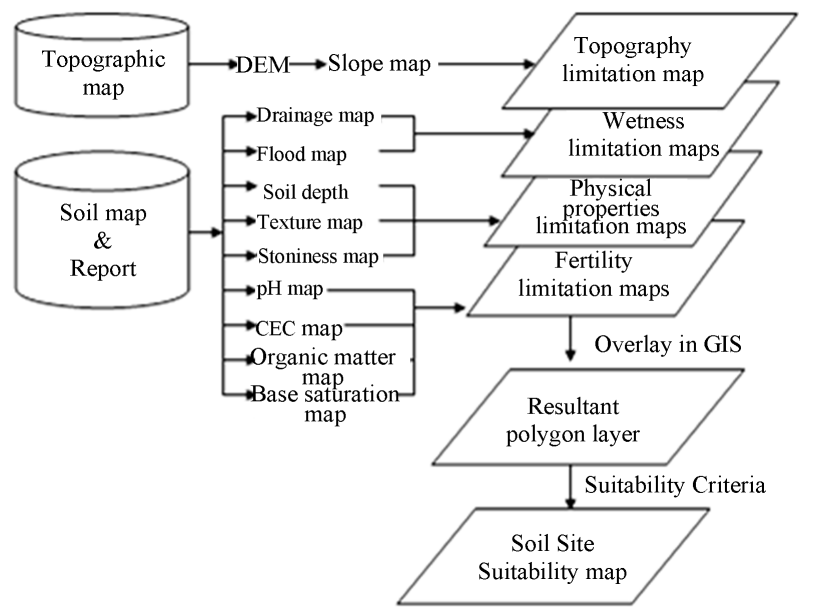

Figure 3. Flowchart of the methodology.

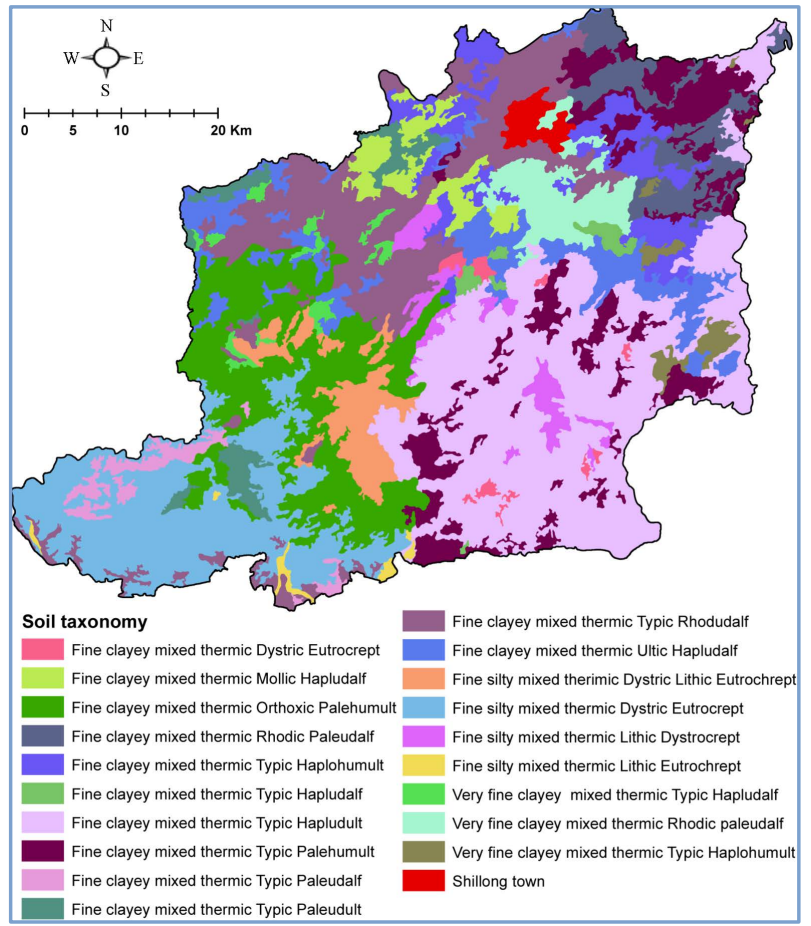

Figure 4. Soil map. graphical area of the district has got very high organic carbon $(4.03 \%-4.23 \%)$. The apparent CEC of soils varies from 3.5 to 33.8 [cmol(+)/kg clay] and base saturation varies from $11 \%$ to $50 \%$.

\subsection{Land Suitability Map}

The land suitability analysis for Khasi mandarin orange indicated that $63 \%$ area of the district is suitable (S) and $37 \%$ area is not suitable $(\mathrm{N})$ for orange cultivation. It is observed that only $1 \%$ (34.54 Sq.Km) area of total geo graphical area (TGA) is highly suitable (S1) which are situated in the Cherapunjee and Mawsynram (World's highest rainfall receiving area) area towards Bangladesh border. From field survey it is also found that the production of orange is high in the area and oranges are larger in size, juicier and sweeter in taste compared to other part of the district. A moderately suitable (S2) area covers $37 \%$ area of TGA which are situated in the undulating area of the Plateau with $8 \%$ - 16\% slope. Marginally suitable (24\% of TGA) areas are found in hill side with 16\% - 30\% slope. The hills with deep gorges and ravines on the southern portion of the district is found not suitable for orange plantation because of very steep slopes (>30\%) and stoniness (Figure 5).

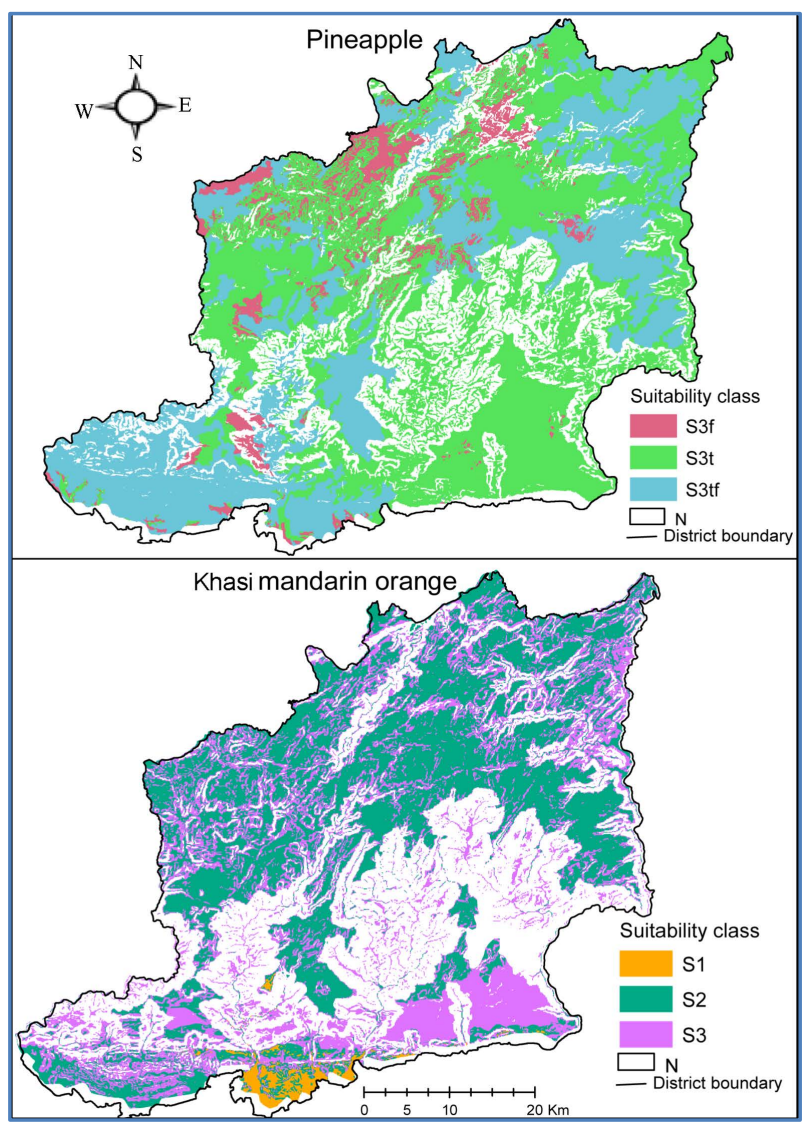

Figure 5. Soil site suitability map for Pineapple and Khasi mandarin orange. 
The suitability map of pineapple resulting from the spatial overlay all thematic layers and application of suitability criteria indicated that the soil sites of the study area are not highly suitable for pineapple (Figure 5). Form the study it is found that $83 \%$ area of total geographical area of the district is marginally suitable (S3) and $17 \%$ area is not suitable $(\mathrm{N})$ to support the crop. The data collected from state directorate of economics and statistics also confirmed that the production of pineapple in the district is less compared to other districts of Meghalaya. It is because of topography (slope and erosion) and soil fertility (base saturation and CEC) which are the major limiting factor for suitability of pineapple. It is also observed the climate is not highly suitable for the crop since the temperature goes below $10^{\circ} \mathrm{C}$ during winter.

\section{Conclusion}

The remote sensing data helps in preparing soil map with limited field survey for profile study and GIS helps in analysis of land suitability with spatial modeling that helps in assessing soil site suitability with higher accuracy. It also gives information on soil or landscape parameters which imparts limitation for the crop. The land suitability analysis provided the information on soil properties that limits crop growth. To assess the accuracy of the results found from the study, the crop yield was checked with the crop statistics obtained from directorate of Agriculture, Meghalaya. It is found that pineapple yield in the study area is less which is $6728 \mathrm{Kgs} / \mathrm{ha}$ compared to $11,128 \mathrm{Kgs} / \mathrm{ha}$ in Ri-bhoi district which produce highest pineapple in the state. It is also observed that since the district is not very suitable for pineapple only 951 ha area is under the crop which is 3513 ha in Ri-bhoi district of Meghalaya. Since both the soil and climatic conditions are suitable for orange the production of orange is highest and farmers adopted the crop because of which the cop covers highest area in the district. Therefore, it is suggested that planners can advise farmers to expand area under orange plantation based on soil suitability map.

\section{REFERENCES}

[1] G. Addeo, G. Guastadisegni and M. Pisante, "Land and Water Quality for Sustainable and Precision Farming," World Congress on Conservation Agriculture, Madrid, 2001.

[2] T. R. Nisar Ahamed, K. Gopal Rao and J. S. R. Murthy, "GIS-Based Fuzzy Membership Model for Crop-Land Suitability Analysis,” Agricultural Systems, Vol. 63, No. 2, 2000, pp. 75-95. http://dx.doi.org/10.1016/S0308-521X(99)00036-0

[3] A. A. Mustafa, S. Man, R. N. Sahoo, A. Nayan, K. Manoj, A. Sarangi and A. K. Mishra, "Land Suitability Analysis for Different Crops,” Indian Agricultural Research Institute, New Delhi, 2011.

[4] FAO, “A Framework for Land Evaluation,” Soils Bulletin 32, Food and Agriculture Organisation, Rome, 1976.

[5] T. N. Prakash, "Land Suitability Analysis for Agricultural Crops: A Fuzzy Multicriteria Decision Making Approach,” International Institute for Geo-Information Science and Earth Observation, Enschede, 2003, pp. 6-13.

[6] J. Dumanski, M. Phipps and E. Huffman, "A Study of Relationships between Soil Survey Data and Agricultural Land Use Using Information Theory,” Canadian Journal of Soil Science, Vol. 67, No. 1, 1987, pp. 95-102. http://dx.doi.org/10.4141/cjss87-009

[7] C. Sys, V. Ranst, J. Debaveye and F. Beernaert, "Land Evaluation Part III, Crop Requirements,” Agricultural Publication No. 7, ITC Ghent, 1993.

[8] T. Bhattacharyya, C. Mandal and S. N. Deshmukh, "Soils and Land Use Pattern in Part of Western Maharashtra," Journal of Indian Society of Soil Science, Vol. 40, No. 3, 1992, pp. 513-520.

[9] R. S. Murthy, L. Venkataratnam and R. K. Saxena, “Application of Remote Sensing Techniques for Land Evaluation and Classification for Agriculture,” In: B. L. Deekshatulu and Y. S. Rajan, Eds., Remote Sensing, Indian Academy of Sciences, Bangalore, 1984, pp. 83-94.

[10] N. Ramarao, “Conformity Analysis of Cotton Crop Using Remote Sensing and GIS,” GISdevelopment.net, 2001.

[11] D. Sarkar, S. K. Gangopadhyay and A. K. Sahoo, "Soil Resource Appraisal towards Land Use Planning Using Satellite Remote Sensing and GIS-A Case Study in Patloinala Microwatershed, District Purulia, West Bengal,” Journal of the Indian Society of Remote Sensing, Vol. 43, No. 3, 2006, pp. 245-260. http://dx.doi.org/10.1007/BF02990653

[12] S. P. Ghosh, A. N. Verma, S. Govind and R. P. Medhi, "Mandarin Orange Decline in North Eastern Hills Region and Its Control,” Research Bulletin 16, ICAR Research Complex for NEH Region, Shillong, 1980.

[13] T. Das Pratibha, T. Liagi and G. Jonali, "Mapping of Potential Citrus Decline Areas of Umling Block of Ribhoi District Using RS and GIS Technique," Journal of Indian Society of Remote Sensing, Vol. 37, No. 2, 2009, pp. 317-324.

[14] "Directorate of Economics and Statistics. Crop Forecaster Reports: Year 1993 to 2003,” Goverment of Meghalaya, Shillong, 2003.

[15] T. M. Lillisand and R. W. Keifer, "Remote Sensing and Image Interpretation,” John Wiley, Singapore, 2004.

[16] IARI, "Soil Survey Manual. All India Soil and Land Use Survey," Indian Agricultural Research Institute, New Delhi, 1970.

[17] FAO, "FAO Guidelines for Soil Profile Description," Food and Agriculture Organisation, Rome, 1977.

[18] SLUSI, “Annual Report,” Indian Agricultural Research Institute, New Delhi, 2008.

[19] FAO, "Guidelines: Land Evaluation for Rainfed Agriculture,” Soil Bulletin No. 52, Food and Agriculture Organisation, Rome, 1983. 